\title{
Robinson Crusoe and the natural mechanick
}

\section{Article}

Accepted Version

Bullard, P. (2019) Robinson Crusoe and the natural mechanick. Études anglaises: revue du monde anglophone, 72 (2). pp. 182-195. ISSN 1965-0159 doi:

https://doi.org/10.3917/etan.722.0182 Available at https://centaur.reading.ac.uk/83539/

It is advisable to refer to the publisher's version if you intend to cite from the work. See Guidance on citing.

To link to this article DOI: http://dx.doi.org/10.3917/etan.722.0182

Publisher: Belles Lettres

All outputs in CentAUR are protected by Intellectual Property Rights law, including copyright law. Copyright and IPR is retained by the creators or other copyright holders. Terms and conditions for use of this material are defined in the End User Agreement.

\section{www.reading.ac.uk/centaur}

\section{CentAUR}

Central Archive at the University of Reading

Reading's research outputs online 


\section{Robinson Crusoe and the Natural Mechanick}

\section{Paddy Bullard, University of Reading.}

In her essay on Robinson Crusoe Virginia Woolf searches for a metaphor to capture her sense of the power of Defoe's novel. She settles on what would be, in any normal setting, a banal household object: a plain earthenware pot. Woolf is thinking of the moment in the novel when Crusoe, who lacks dry storage for his first cereal harvest, works out how to make a rough pipkin: "No joy at a Thing of so mean a Nature was ever equal to mine," says Crusoe, "when I found I had made an Earthen Pot that would bear the Fire" (Defoe 2007, 103). Not only has Defoe's hero solved his storage problem, he can now boil up broth. These apparently instrumental ends have a wider artistic significance for Woolf. The maker's knowledge that Crusoe acquires as he fashions the pot fixes a whole order of representation. This order encompasses the narrator's sublime solitude, and somehow makes real the vast spaces that isolate him. "By believing fixedly in the solidity of the pot and its earthiness", Woolf explains, Defoe "has subdued every other element to his design; he has roped the whole universe into harmony". In all this, the correspondence between the unrefined power of Defoe's narrative and Crusoe's rude manufacture is strongly implied:

To dig, to bake, to plant, to build - how serious these simple occupations are; hatchets, scissors, logs, axes - how beautiful these simple objects become. Unimpeded by comment, the story marches on with magnificent downright simplicity. (Woolf, 75, 74)

Woolf's reading of Crusoe is as resonant as ever in the twenty-first century. Her choice of a plain clay pot to stand in for Defoe's novel anticipates later material-cultural turns: it encourages us to retrofit a theory to the thing. Cynthia Wall focuses on the "joy at a Thing" that some other Crusoeian objects raisins, umbrellas - seem to emit: they "give out their pleasures because they are reality and, unlike God's signs, are made by Crusoe himself (...) Things were standing in a light of their own and, on their own in texts, generated their particular cultural heat" (Wall 112). Ilse Vickers identifies Crusoe's 
material world with the "history of trades" projects undertaken by the early Royal Society: both were "preoccupied with the 'world of things' and (...) it is not just 'things' but more specifically 'the making of things' that demands his attention [and] affects the style of his narrative" (Vickers 127). By showing how for Defoe "simple objects" like the earthenware pot belong to a continuous conceptual order with the "simple occupations" by which they are made and used, Woolf reminds us how these objects (as Nigel Thrift puts it) “do far more than represent” (Thrift 239). Crusoe's pot might almost have the power to form, rather than simply reflect, an unfolding understanding of its maker's world (Tilley 318-22).

When Vickers categorizes Crusoe as homo faber, and Woolf connects the things he makes to the "magnificent downright simplicity" of Defoe's novel, they are making bold connections between material craft and literary making, and they do so for argumentative effect. There is no doubt that their pronouncements get at something near the heart of Robinson Crusoe. They touch on the pleasure-yielding urges to make and to accumulate for which its narrative gives such effectively regulated provocation and satisfaction. But the straightforwardness that is so important for Woolf's and Vickers's statements needs qualification. While Defoe was of course a projector and a practical progressive, he was also a satirist, and there is an undertow of scepticism and irony in his treatment of mechanical processes that runs hard against the novel's optimistic swell.

This essay argues that these counter-currents are crucial to its literary effect. We will look at three reasons for questioning the received account of Crusoe as homo faber, or handicraftsman-hero. Our first point is largely contextual. Defoe comments often on artisans and manufacturers in his journalism, both before and after he writes Robinson Crusoe, but he does so invariably with contempt. This contempt seems to be at odds with readings like those of Vickers and Woolf. It is not that Defoe thinks skilled craftsmen have no place within the modern world. He thinks simply that their knowledge is stagnant, and that their way of viewing things is inert. Manufacturers, like Crusoe on his island, can generate material surplus, but they have no means of giving it meaningful value. They cannot translate wealth into riches - only merchants and factors can do that. Critics have dealt with this idea when exploring the economic implications of Robinson Crusoe, but its significance for the 
material culture that the novel expresses remains unclear (Novak; Watson). This leads to a second point. Woolf's rhapsody on an earthenware pot tempts us to forget that Crusoe insists, often with curious elaboration, on the unloveliness of nearly everything that he makes. Defoe's deployment of special linguistic resources to describe the ugliness of his hero's manufactures raises a critical problem. Why is he so resistant to the more common material culture narrative, that processes of making have their own natural tendency to improvement, refinement, and even to beauty?

(Greenhough 121) A third point involves a tentative answer to this question. When Defoe writes about making things, there is always an implication that he is also thinking about other things: the making of money, of knowledge, of political states. To whatever extent economics, information or statecraft are made analogous with handicraft, questions about the relation of form to function are bound to arise, and those questions are soon aestheticized. Robinson Crusoe is read often as an allegory of politics in the age of party. The evidence adduced in this essay suggests that it is both more and less than that, and that the affordances of political meaning that are offered up by the material culture it describes are not consistent with one another.

In the text of Robinson Crusoe itself there is evidence at least of an ambivalent attitude to the value of mechanical expertise and material practice. The long sequence of heroic handiworks that Crusoe pursues in the middle of the novel casts a warm light over it, and can make it difficult to assess, but the general sentiment is consistent. In the first instance, Crusoe is careful to identify himself as belonging to a rank significantly above that of the artisan or manufacturer, in order to distinguish himself from that class. The assumption is there in the report of his father's declaration

that mine was the middle State, or what might be called the upper Station of Low Life, which he had found by long Experience was the best State in the World, the most suited to human Happiness, not exposed to the Miseries and Hardships, the Labour and Sufferings of the 
mechanick Part of Mankind, and not embarass"d with the Pride, Luxury, Ambition and Envy of the upper Part of Mankind. (Defoe 2007, 6)

In addition to its main message about social rank, this passage sets up an important narrative premise for the rest of the novel: that Crusoe is a blank slate as far as knowledge of manufacturing processes is concerned. This will mean that his experiences on the island are available to prove, later on, that any technical art can be mastered by reason alone (so long as there is enough time). In these early sections of the novel Defoe works hard to keep his hero innocent of mechanical knowledge, as though he were conscious that a young man seeking his fortune in the great world would be more likely than not to pick some up. During his early trading expeditions Crusoe is able always to ship himself as a gentleman, "so I neither had any Business in the Ship, or learn"d to do any", and he presents this omission in retrospect as regrettable and a little odd (Defoe 2007, 16). But it means that he can reserve himself from hands-on work to learn only the most rational and mathematical parts of navigation during a later voyage, "how to keep an Account of the Ship's Course, take an Observation; and, in short, to understand some things that were needful to be understood by a Sailor" (Defoe 2007, 17). Even during his time as a captive in Africa Crusoe avoids acquiring manual skills. He turns out to be unusually lucky as a fisherman, which sets up his eventual escape on his master's fishing boat. But hunting for food in not a banausic activity, and he loses no status by it (Peacham 12-13: "if a Noble man borne in captiuitie, or constrained through any other necessitie, shall exercise any manuall occupation or Art, hee by the opinion of some, loseth his Nobilitie Ciuill, but not Christian"; compare Xenophon, 414-5 [4.2-3]). The slaves with whom Crusoe works, by contrast, have mechanical skills that seem almost to substitute for their identities. One is a very good swimmer, which means that Crusoe can push him off the escape-boat with an apparently clear conscience (Defoe 2007, 21). The other, the boy Xury, has a natural dexterity that seems if anything to guarantee his servitude. Crusoe remarks that Xury "was a much better workman than I" at, for example, the slaughtering and skinning of wild animals, but this unexpected manual aptitude, rather than humanizing Xury in Crusoe's mind, contributes something decisive to the license that he takes in selling him on as a slave a few pages later (Defoe 2007, 26). 
The opening pages of Defoe's novel suggest that Crusoe considers "the mechanick Part of Mankind" to be degraded socially. This is an opinion that one would not expect, perhaps, from someone modest enough to claim only "the upper Station of Low Life" for themselves. In several of Defoe's writings of the 1720s one finds evidence that this was a settled prejudice of Defoe's. In The Complete English Tradesman (1725) he has special scorn for any slow-witted person who aspires to make their fortune in the merchant's fast-paced trade:

he should have been the Manufacturer, not the Factor; he should have stood by the Shuttle and the Warping-Mill, not come to the Buying and Selling; indeed he is a kind of natural Mechanick, viz. Nature cut him out to be a mere Mechanick, not a Tradesman; to make the Work, not buy and sell it; and his is out of his Element when he is out of the Loom (Defoe 1975, 236-7)

This sort of "thick-headed Wretch" is in fact no better than a weaver's shuttlecock himself, good only of repetitive movement, incapable of improvisation or evolution. It is particularly interesting to see Defoe using the phrase "natural Mechanick" here with such clear derogatory intent. The negative connotation was less obvious when he had used the same colligation six years earlier in Robinson Crusoe. As Robinson sets about making a table he admits that "I was yet but a very sorry Workman, tho" Time and Necessity made me a compleat natural Mechanick soon after, as I believe it would do any one else" (Defoe 2007, 62). Here "natural Mechanick" sounds like an admirable thing to be, but in both cases the technological and social context is significant. We know from the Essay on Projects that Defoe was particularly admiring of mechanical looms. In a passage where he doubts that any serious technical progress has been made since the discovery of gunpowder, printing and the compass, he admits that one invention "owes more to true genuine contrivance, without borrowing from any former use, (...) a mechanic engine contrived in our time called a knitting-frame". But Defoe is alert to the potential that this truly progressive machine has for degrading its operators, and for creating new divisions in the social hierarchy. Two years later, when making a survey of the working portion of British society in A Plan of the English Commerce, Defoe placed "mere drudges" at the bottom of the scale, and one small step above them "those who, tho" labouring perhaps equally with the other, have yet some Art mingled with their Industry, and are to be particularly instructed and taught how to perform their Part, and those are called Workmen or Handicrafts" (Defoe 1728, 12; compare Defoe 1726, 12: from "Apprentices to Merchants, Wholesale-Men, and the like, I must descend to the 
Apprentices of meaner Tradesmen, and yet not to the labouring Trades neither, that is to say, the Handicrafts, Artificers, and the like..."). Such workmen were distinct again from the instructors and guides of the industry - "these are call"d Artists, Mechanicks or Craftsmen" - and the "Dealers" or merchants who are one step in turn above them. In Crusoe what Defoe seems to be imagining is a "natural Mechanick" who rises to the capacity of artist-craftsman without passing through the intervening stage of "instructed" handicraftsman. He becomes a master without stooping to the mastery of any one mechanical process. This is a fantasy of mechanical expertise that cannot be taken seriously by anyone with experience of manufacturing processes, and Defoe is clearly presenting it as a constructive fiction, if not positively as an ironic impossibility.

Some important passages in Robinson Crusoe become easier to interpret when one applies to them these distinctions - of workmen from artists, of undertakers of handicrafts from true craftsmen. In each case, the most striking thing is the care with which Defoe divests Crusoe's workmanship of intrinsic value. There is no glimmer of recognition here that skilled manual arts might involve any especially valuable extension of cognitive processes through haptic experience, or any other personal knowledge of the material world. All suspicion of mystery - in the mechanical sense of the word of which Crusoe makes almost figurative use when he recalls letting Friday "into the Mystery, for such it was to him, of Gunpowder" (Defoe 2007, 187) - is removed from his island workshop:

as Reason is the Substance and Original of the Mathematicks, so by stating and squaring every thing by Reason, and by making the most rational Judgment of things, every Man may be in time Master of every mechanick Art. I had never handled a Tool in my Life, and yet in time by Labour, Application and Contrivance, I found at last that I wanted nothing but I could have made it, especially if I had had Tools; however, I made abundance of things, even without Tools, and some with no more Tools than an Adze and a Hatchet, which perhaps were never made that way before, and that with infinite Labour: For Example, If I wanted a Board, I had no other Way but to cut down a Tree, set it on an Edge before me, and hew it flat on either Side with my Axe, till I had brought it to be as thin as a Plank, and then dubb it smooth with my Adze. It is true, by this Method I could make but one Board out of a whole Tree, but this I had no Remedy for but Patience, any more than I had for the prodigious deal of Time and Labour which it took me up to make a Plank or Board: But my Time or Labour was little worth, and so it was as well employ"d one way as another. (Defoe 2007, 59)

The language that Defoe uses here is one of open explication ("stating and squaring") and rational, systematic specification, even though the communicative context that one would expect for those actions - of instruction and apprenticeship - is irrelevant to Crusoe's current circumstances. The list 
of "Labour, Application and Contrivance" is presented as complete in its sufficiency. There is no component of personal expertise, however, to connect rational "Contrivance" - a word that we have seen Defoe use in the Essay on Projects to denote the most original and progressive forms of invention - back to the basic categories of bodily "Labour" and ethical "Application". The rhetorical weighting of these sentences feels almost willfully clumsy and ill-contrived. Complete control and easy attainment are boasted in the same breath that barely practicable levels of toil are confessed. At one moment Defoe wants Crusoe (who has "never handled a Tool in my Life" and suspects that he could have got along "even without Tools") returned to a state of pre-technical primitivism. At the next he overturns the conjecture by admitting how much more how much more he could do "if I had had tools". Tools are the objects that encode most efficiently the mechanic gestures and techniques of successive generations of manufacturers, and those are precisely the sorts of traditional knowledge that Defoe is trying to downplay in this passage. The notion of cutting down a tree to make a single plank is especially, even conspicuously absurd, especially given that he has all the tools necessary to make boards by wedging and hammering. Defoe must have been conscious of this absurdity, given that elsewhere he reports a similar practice in certain remote Russian communities as a peculiar curiosity (Defoe 1728, 36: "in Russia and Muscovy, when for want of Commerce, La- bour was not assisted by Art; they had no other Way to cut out a large Plank, but by felling a great Tree, and then with a multitude of Hands and Axes hew away all the Sides of the Timber, till they reduc"d the middle to one large Plank"). Everything in this passage is at the service of Defoe's vision of a completely rational and yet completely unskilled process of manufacture. But Crusoe can only attain to it by a total devaluation of his personal "Time" and "Labour" - the very variables by which the "worth" of real manufacturers is usually assessed. The economic logic of production here can go in only two directions: towards systems of factory automation that were still largely the stuff of fantastic "projects" in 1719; or towards systems of enslaved labour.

The denigration of skilled manufacturing in Crusoe and elsewhere is the negative side of a positive tendency: Defoe's enthusiastic championship of merchants and dealers. With its trans-global scope, its focus on specially required kinds of knowledge, and its distinct political implications, the 
productive logic of Crusoe is consistent with pronouncements on similar subjects that Defoe was making at the beginning of the century. Take for example the manifesto for free trade that he published in The Review in 1706:

The artificers or handicrafts-men are indeed slaves; the gentlemen are the plowmen of the nation, but the merchant is the support and improver of power, learning and fortunes. A truebred merchant is a universal scholar, his learning excels the mere scholar in Greek and Latin as much as that does the illiterate person that cannot write and read. He understands languages without books, geography without maps; his journals and trading voyages delineate the world... He is qualified for all sorts of employment in the state by a general knowledge of things and men... (Defoe 1951, 124-5)

The allusion to slavery is figurative and comparative, but it anticipates the logic of sovereignty and control that plays out in Crusoe. It is consistent also with Defoe's later rationalistic rejection of skilled expertise: just as Crusoe is a manufacturer without mechanical instruction, so Mr Review's merchant had been a geographer without maps, a linguistic without books. Nullius in verba is their shared motto. Manufacturers, like husbandmen in lucky climates, can produce abundance and riches, but they depend upon the universal scholarship of the tradesman, by whose agency alone those riches can be translated into a universal "wealth" (that is, into exchange value): "What was the land in Barbadoes good for", asks Mr Review, "when the island was unpossessed by us? It was as rich as now, the fund was there, - - but that trade gave that fund a value. It was a fund and no fund - a fund of nothing" (Defoe 1951, 112-3). When Defoe writes of "the fund" he means the foundation or bottom of a potential trade - he is using the same special sense of the word that he deploys in the introduction to The Compleat English Tradesman, when he proposes "to describe the English or British Product, being the Fund of its inland Trade, whether we mean its Produce as the Growth of the Country, or its Manufactures" (the passage is quoted to illustrate "fund, $n .6$ " in the $O E D$; Defoe 1727, 5). But it is clear that he is playing with other recently developed financial senses of the word as well: this fund will produce no funds, no instruments for further investment, no stock for exchange. It is a word that Defoe puts under even greater stress in Robinson Crusoe when Friday speculates on the "wonderful Fund of Death and Destruction" that must be concealed within Crusoe's most significant instrument, his gun - a different "fund of Nothing", one might say (Defoe 2007, 178). In each of these passages Defoe presents a different aspect of a quintessentially modern paradox: that the tangible things people grow or craft or manufacture will, from now on, have an arbitrary relationship with all the really 
important circulations of value that are defined in terms of capital, credit and wealth. All that is solid melts into air.

In the last section we reviewed evidence that Defoe understood a distinction between manufacturing processes that show, on the one hand, elements of rational determination and, on the other, those that do not, because they are mere handicrafts, constituted only by haptic skills and social inheritances. There is some consistency in the negative rhetorical weight that Defoe applies to the latter category of manufacturing work. This section will look in more detail at the way Defoe represents Crusoe's manufactures. It focuses in particular on the theme of ugliness or clumsiness that runs through many of these descriptions. I want to argue that there is a positive reason for this emphasis on ill contrivance, having to do with the function of Robinson Crusoe as a sort of prototypical enlightenment conjectural history. Defoe wishes to present a scheme of material production in which the bare components of manufacture - labour, raw materials, instrumental ends, time - are always legible and deducible to the reasoning observer. He is careful to make sure that there is no intervening layer of purely personal knowledge, of artisanal mystery, of refinement or ornament, that might obscure this conjectural vision.

Ugliness is the guarantee that Defoe offers his readers of the traceability of Crusoe's achievements on the island to their most basic components. During the first few years of residence on the island Crusoe directs his work towards living and growing things: plants and animals to eat, hedges for protection, caves for shelter. These simple objects, like the conventionally contrived things that Crusoe rescues from his ship, are generally treated as givens or necessities that do not warrant much evaluative comment. It is when Crusoe begins to make his own pots out of the island's earth, pots that he hopes will allow him to store up a reserve stock of grain, that he begins to insist on his 
shortcomings as a maker: "It would make the Reader pity me, or rather laugh at me, to tell how many awkward ways I took to raise this [clay] paste, what odd misshapen ugly things I made (...) I could not make above two large earthen ugly things, I cannot call them Jarrs, in about two Months Labour" (Defoe 2007, 102). The reader's commiseration is begged again when Crusoe begins to make clothing: "I made most piteous work of it" (Defoe 2007, 114). When Crusoe manages to contrive the firing of his pots, producing "three very good, I will not say handsome Pipkins", it is as though Defoe seeks to highlight the life-changing usefulness of these objects by presenting them in terms of raw functionality, hedged around by a tangle of negative constructions: "After this Experiment, I need not say that I wanted no sort of Earthen Ware for my Use; but I must needs say as to the Shapes of them, they were very indifferent" (Defoe 2007, 103). In a particularly heightened passage Crusoe offers a "Scetch of my Figure" that returns insistently to the shocking effect created by his home-made fur clothes: they have "a most barbarous Shape", especially when complemented by his whiskers, which were "of a Length and Shape monstrous enough" (Defoe 2007, 127). These protests about ugliness of form persist even when Crusoe begins to report improvements in his skill as a maker a few pages later:

Besides this, I arriv"d at an unexpected Perfection in my Earthen Ware, and contriv"d well enough to make them with a Wheel, which I found infinitely easyer and better; because I made things round and shapable, which before were filthy things indeed to look on. But I was never more vain of my own Performance, or more joyful for any thing I found out, than for my being able to make a Tobacco-Pipe (...) tho" it was a very ugly clumsy thing (...) (Defoe 2007, 122)

In each of these passages the words with which Defoe describes Crusoe's manufactures, and insists on their unattractiveness, have the same new-made uncouthness and awkwardness as their referents.

Crusoe calls his pipe "clumsy", for example, a word he uses again for his umbrella a few pages later (“a great clumsy ugly Goat-Skin Umbrella", Defoe 2007, 127). Ben Jonson had singled out the word for use by the ridiculous Tibullus in Poetaster (1601) as a grotesque new coinage ("clumsy chilblained judgment" - usually “clumsy" meant stiffened with cold) (Jonson 1995 [V.280], 240). Developing the oddness of the word further, Defoe anticipates the earliest transference of the word recorded in the $O E D$ to describe awkwardly-made objects (1758) by some forty years ("Clumsy", $O E D, 4 a)$. The $O E D$ also indicates that "ugly" was a word that retained terrible and horrible 
associations in the early modern period, and that "filthy" ("filthy things indeed to look on") was usually reserved for similarly violent descriptions of dirt or squalor ("Ugly", $O E D$, especially $2 \mathrm{~b}$ and 6a, which cited Defoe; "Filthy", $O E D, 2)$. Defoe's use of "shapable" to signify good form, quoted above, is the earliest recorded in the $O E D$ ("Shapeable", $O E D, 2$ ). It is likely that Crusoe's first readers would have been more sensitive to the rough novelty of these usages than we are, and perhaps more understanding of the way Defoe is aligning new-made words with newly-contrived things. We can still get a sense, however, that he is placing a special emphasis on these designations and ideas. By insisting on the filthiness of his manufactures he is saying something specific about their elementality, their nearness to the unimproved or natural states of mud and branch and fur. At the same time he is showing that there is something astonishing about their attainment to recognizable and sufficiently useful form while they are still so close to that elemental stage.

The introduction of a potter's wheel strikes a discordant note in the main passage quoted above. It is curious that Defoe gives no explanation for how he contrives it, especially given that he had written previously in his journal of the impossibility of making "the Iron Gudgeons for the Spindle or Axis of [a] Wheel to run in": "I had no Notion of [the pattern for a wheel], neither did I know how to go about it" (Defoe 2007, 64). But the wheel does fit in with an aspect of Crusoe's experience that is often noticed by commentators. Although Crusoe arrives on the island empty handed, his efforts to survive on it, and his later triumph over all incomers, depend entirely on technologies imported from the Europe, such as iron tools, woven textiles and firearms. Most of these he rescues from the wreck of his own and another ship. What Defoe presents sometimes as a narrative in which a one-man culture of manufacture evolves from nothing depends in fact on an artificial head start. Crusoe is ready to acknowledge how crucial his lucky find of tools is for his survival. Defoe also gives an extra hint of its significance by prefiguring it in an earlier part of the novel. When Crusoe arrives in the Brasils and begins to establish his ingenio or sugar factory, he sends to London for credit banked with his landlady. She returns it to him in the form of goods, and the merchant who advises her includes in the shipment, "without my Direction (...) all Sorts of Tools, Ironwork, and Utensils necessary for my Plantation, and which were of great Use to me" (Defoe 2007, 33). 
Throughout the book iron equipment proves necessary to Crusoe, and that necessity is entirely unanticipated. Defoe is emphasising again the directness of Crusoe's encounter with the experience of making, its lack of personal mediation. One notices that Defoe lets us catch Crusoe trying to downplay the significance of the technological mediation provided by his tools - for example, when he reports that

I improv"d my self in this time in all the mechanick Exercises which my Necessities put me upon applying myself to, and I believe cou"d, upon Occasion, have made a very good Carpenter, especially considering how few Tools I had (Defoe 2007, 122).

The allusion in this passage to Joseph Moxon's Mechanick Exercises, Or, the doctrine of handy-works (1677-80 as serial; second volume on printing, 1683), the most comprehensive account available to Defoe of the basis for technological progression in artisanal practices, has a note of irony about it. Crusoe falls a long way short of the "curious" expertise towards which Moxon describes each of his mechanical trades developing. In these passages Defoe mixes rueful acknowledgments of his lack of skill with barely convincing protestations about the "unexpected Perfection" (Defoe 2007, 122) to which he progresses. His journal contains one particularly memorable distortion of retrospect, when his efforts to make a table lead to an acknowledgment of being "yet but a very sorry Workman, tho" Time and Necessity made me a compleat natural Mechanick soon after, as I believe it would do any one else" (Defoe 2007, 62). The phrase "compleat natural Mechanick" sounds like the title of a trades encyclopaedia such as Moxon's. But the word "natural" could point in different directions: towards the abstraction of natural reason and philosophy, or towards the ugly and entangled practicality of "botching" (Defoe 2007, 114). In what sense can Crusoe, whose comfort on the island depends on tools developed through European synthetic crafts, be described as either "compleat" or "natural" in his manufacturing?

One answer to this question - an answer that I want to explore in what remains of this essay is that the persistent note of ruefulness or irony that can be heard in so many of Crusoe's statements about his manufactures should make us cautious about taking his rhetoric of nature, perfection and completeness at face value. Without doubt Defoe invites us to read Crusoe's experience on the island as an anthropological test case. It is a conjectural narrative, a thought experiment in which an 
acculturated European is returned to a nearly natural state and invited to reconstitute a comfortable, domestic and finally aggressively political life out of very basic (if not entirely natural) components. But it is important that we do not read Crusoe's story in too Hobbesian or Rousseauian a light. It was not Defoe's habit to think about social reconstitution in terms of pristine moments at which artificial state persons or original contracts are formed. When Defoe wrote about foundational socio-political forces he did so in terms of a parabolic movement, involving a retreat and a return more than linear evolution. He imagined politicians dipping back into the sources of original power in their polities, rather than stripping them down to their elements and reconstituting them. Although the arc in Robinson Crusoe is a long one in terms of a human life, it also describes a partial retreat into the primitive, rather than a total revolution. Before Crusoe this rhetoric of retreat and return is prominent in Defoe's enduringly popular The True-Born Englishman (1700), which contains its own mythopoeic origination narrative. Before England is populated by men and women the land is home to "a devil of black renown", who establishes pollution rather than purity as the foundational element of the nation: "From whose mixed relics our compound breed, | By spurious generation does proceed" (Defoe 1997, 41). Defoe writes in the poem about revolutionary moments ("The Governments ungirt when Justice dies, | And Constitutions are non-entities"), but those moments are themselves complex, not pure:

If to a King they do the Reins commit,

All men are bound in Conscience to submit:

But then that king must by his Oath assent

To Postulata's of the Government;

Which if he breaks, he cuts off the entail,

And Power retreats to its Original. (Defoe 1997, 48)

Defoe seems to have considered the last line here, "Power retreats to its Original", to be the most important one in the poem. Its resonance for him is especially evident in the important essay that he wrote for The Post-Man (25-27 December 1701) "The Original Power of the People of England", where it is requoted and woven into the prose: "I would endeavor to make way, by retreating to originals, for every member to perform its proper function, in order to put the general body into its regular motion" (Defoe 1997, 104). Just as Crusoe dispenses with beauty of form and refinement of manufacture when he sets about making pots and umbrellas, so Defoe is determined not to let the beautiful symmetry of established institutions distract him from the process of retreat and renewal: 
"for notwithstanding all the beauty of our constitution, and the exact symmetry of its parts, about which some have been very elegant, this noble well-contrived system has been over-whelmed" (Defoe 1997, 91). When incomers threaten to overwhelm Crusoe on his island, he too depends on points “whither I could retreat upon Occasion” (Defoe 2007, 217), "a Place of Security, and such a Retreat as I wanted" (Defoe 2007, 151) - and a "safe Retreat", moreover, "where, I dare say, no Savage, had he been at the Mouth of it, would be so hardy as to venture in" (Defoe 2007, 149). Just as Defoe does withhold tools from Crusoe in his state of near-nature, the original to which Crusoe retreats at moments of crisis is not elemental: it is itself pre-prepared, well constituted, built and supplied.

So Crusoe's earthenware pot, the symbol of solidity and earthiness by which Defoe, in Virginia Woolf's account, "has roped the whole universe into harmony", may not have quite the power to bring order and beauty that she supposes. An investigation of the language and figuration with which Robinson Crusoe represents the material world suggests a prevailing movement of thought that is more recursive than the one described by Woolf, and more resigned to the ugliness and irregularity that appears when providence is viewed from partial, human perspectives: "still as we are all the Clay in the Hand of the Potter", Crusoe catechizes, "no Vessel could say to him, Why hast thou form"d me thus?" (Defoe 2007, 177). It may be that a better artisanal symbol for Defoe's novel, and one to which he was drawn often, is that of a checker-work surface, of the sort one might see on a marquetry chess board or a tessellated pavement. "How strange a Checquer Work of Providence is the Life of Man!" exclaims Crusoe, "and by what secret differing Springs are the Affections hurry"d about as differing Circumstances present!” (Defoe 2007, 132, and see endnote on 291). In the closing pages of the novel he sums it up as "a Life of Providence's Checquer-Work, and of a Variety which the World will seldom be able to show the like of" (Defoe 2007, 256). This imagery corresponds with Defoe's words in the preface to the novel, which stresses diversion and plurality, and sets out his aim to "justify and honour the Wisdom of Providence in all the Variety of our Circumstances" (Defoe 2007, 3). In early modern homilies checker-work was a common symbol for mixed experience of joy and sorrow in human life: "Gods Providential Dealings with his people in this world", wrote the Baptist minister Hercules Collins in 1684, "is like Chequer-work, there is the dark, as well as the light 
side of Providence, the most Refin"d and best State and Condition of the best Saints are mixed" (Collins 1684, 28; Bury 1693, 16). As we have seen, Defoe attributes to the trader (though never to the maker) a capacity to synthesize at least some of that complexity: "the merchant by his correspondence reconciles the infinite variety which, as I noted, has by the infinite wisdom of Providence been scattered over the face of the world" (Defoe 1951, 125). In the confined space of Crusoe's island this variety is brought within bounds, so that certain hesitant experiments in rational making can be carried out, where the maker can be free from the pressures of time, and of the endlessly varied possibilities offered by a navigable world. In Robinson Crusoe Defoe does not offer a fully worked out vision of natural crafts and mechanics built up from first principles. He needs his hero to be more various and inconsistent than that. Crusoe shows himself to us as both thoughtful and short-sighted, attentive to the world and inattentive, skilled and clumsy, equipped with tools and yet half-naked. We expect that Defoe has set out to write a conjectural history of life stripped back to its most simple elements, but the story he delivers instead is a narrative of retreat that remains involved in our own social and material entanglements.

\section{References.}

Bury, Edmund, Death Improved. London, 1693.

Cohen, Margaret, The Novel and the Sea. Princeton: Princeton UP, 201.

Collins, Hercules, Counsel for the Living. London, 168.

Defoe, Daniel, The Behaviour of Servants in England Inquired Into. London, 1726.

Defoe, Daniel, The Best of Defoe's Review: An Anthology, ed. William L. Payne. New York:

Columbia UP, 1951.

Defoe, Daniel, The Complete English Tradesman, in Familiar Letters. London, 1727.

Defoe, Daniel, Robinson Crusoe, ed. Thomas Keymer and James Kelly. Oxford: Oxford UP, 2007

Defoe, Daniel, A Plan of the English Commerce. Being a compleat prospect of the trade of this nation. London, 1728.

Defoe, Daniel, Selected Writings of Daniel Defoe, ed. James T. Boutlon. 1965; reprinted Cambridge: Cambridge UP, 1975. 
Defoe, Daniel, The True-Born Englishman and Other Writings, ed. P.N. Furbank and W.R. Owens. Harmondsworth: Penguin, 1997.

Greenough, Horatio. "Structure and Organization", in Form and Function: Remarks on Art, Design, and Architecture. Berkeley: University of California Press, 1947. 113-30.

Jonson, Ben. Poetaster, ed. Tom Cain. Manchester: Manchester UP, 1995.

Liu, Lydia H. "Robinson Crusoe's Earthenware Pot: Science, Aesthetics and the Metaphysics of True Porelain", in Romantic Science: The Literary Forms of Natural History, ed. Noah Heringman.

Albany: SUNY Press, 2003. 139-72.

Novak, Maximillian E., Economics and the Fiction of Daniel Defoe. Berkeley: University of California Press, 1962.

Peacham, Henry, The Compleat Gentleman, Fashioning him Absolute in the most Necessary \& Commendable Qualities concerning Minde or Bodie. London, 1622

Thrift, Nigel, Non-Representational Theory: Space/Politics/Affect. London: Routledge, 2007.

Tilley, Chris, An Ethnography of the Neolithic: Early Prehistoric Societies in Southern Scandanavia. Cambridge: Cambridge UP, 1996.

Vickers, Ilse, Defoe and the New Sciences. Cambridge: Cambridge UP, 1996.

Wall, Cynthia S., The Prose of Things: Transformations of Description in the Eighteenth Century. Chicago: Chicago UP, 2006.

Watson, Matthew, "Crusoe, Friday and the Raced Market Frame of Orthodox Economics Textbooks", New Political Economy, 23 (2018): 544-59.

Woolf, Virginia, "Robinson Crusoe", in The Collected Essays of Virginia Woolf, 4 vols. London: Hogarth Press, 1966-7, vol. 1. 69-75.

Xenophon, Memorabilia, Oeconomicus, tr. E.C. Marchant et al., LCL 168. Cambridge, Mass.: Harvard UP, 2013. 